\title{
NOTAS SOBRE O PROCESSO CONSTITUINTE CHILENO 2019-2020 ${ }^{12}$
}

NOTAS SOBRE EL PROCESO CONSTITUYENTE CHILENO 2019-2020

\author{
NOTES ABOUT THE CHILEAN CONSTITUENT PROCESS 2019-2020
}

\author{
Eric Eduardo Palma Gonzalez ${ }^{3}$
}

Resumo: $\mathrm{O}$ artigo expõe as principais características do atual processo constituinte chileno, a partir de um conjunto perguntas que procuram ordenar o relato do que vem ocorrendo no Chile desde 18 de outubro de 2019. Trata-se de um exercício descritivo e valioso que procura explicar o fenômeno constitucional em conexão com a realidade sociopolítica chilena, superando o âmbito da dogmática constitucional.

Palavras-Chaves: Processo constituinte no Chile; Convenção Mista; Convenção Constitucional; Lei 21.200; Lei 21.216; Movimento social no Chile; Movimento de Unidade Social.

Resumen: El artículo expone las principales características del actual proceso constituyente chileno, a partir de un conjunto de preguntas que procuran ordenar el relato de lo que viene ocurriendo en Chile a partir del 18 de octubre de 2019. Se trata de un ejercicio descriptivo y valorativo que procura explicar el fenómeno constitucional en conexión con la realidad sociopolítica chilena, superando el ámbito de la dogmática constitucional.

Palabras clave: Proceso constituyente en Chile; Convención Mixta; Convención Constitucional; Ley 21.200; Ley 21.216; Movimiento social en Chile; Movimiento de Unidad Social.

\footnotetext{
${ }^{1}$ Artigo recebido e aceito para publicação em abril de 2020.

${ }^{2}$ Tradução do original em espanhol por Isabella Oliveira de Carvalho e Victoria Lourenço de Carvalho e Gonçalves: Mestrandas pelo Programa de Pós-graduação em Direito Constitucional (PPGDC) e Graduadas em Direito pela Universidade Federal Fluminense (UFF). ORCID: https://orcid.org/0000-0002-8426-5457 e ORCID: https://orcid.org/0000-0001-7777-1952, respectivamente. Revisão da tradução por Enzo Bello: Doutor em Direito pela UERJ. Estágio de Pós-Doutorado em Direito pela UNISINOS. Estágio de Pós-Doutorado em Serviço Social pela UFRJ. Professor Adjunto da Faculdade de Direito da UFF. Professor e ex-coordenador (2014-2016) do Programa de Pós-Graduação em Direito Constitucional (PPGDC) da UFF. Editor-chefe da Revista Culturas Jurídicas (www.culturasjuridicas.uff.br) - Qualis Direito A2. Membro do Núcleo de Estudos e Projetos Habitacionais e Urbanos (NEPHU) da UFF. ORCID: https://orcid.org/0000-0003-3923-195X.

${ }^{3}$ Doutor em Direito pela Universidade de Valladolid, Espanha. Mestre em História pela Universidade do Chile. Bacharel em Direito e Ciências Sociais pela Universidade do Chile. Professor catedrático da Faculdade de Direito da Universidade do Chile. Professor de História do Direito, História institucional dos séculos XIX e XX do Chile, Pedagogia Jurídica e Metodologia da Pesquisa Jurídica. Advogado.

Escrevo este artigo no contexto de minhas obrigações como acadêmico participante do plano de pesquisa da Faculdade de Direito da Universidade do Chile. https://orcid.org/0000-0002-8804-6278.
} 
Abstract: The article exposes the main characteristics of the current Chilean constituent process, from a set of questions that seek to order the report of what has been happening in Chile since October 18, 2019. It is a descriptive and evaluative exercise that seeks to explain the constitutional phenomenon in connection with the Chilean social political reality, overcoming the scope of constitutional dogmatics.

Keywords: Constituent Process in Chile; Mixed Convention; Constitutional Convention; Statute 21.200; Statute 21.216; social movement in Chile; Social Unity Movement.

\section{Introdução}

Este artigo tem por propósito fundamental apresentar uma visão panorâmica e geral dos acontecimentos que compõem o processo constituinte chileno, na etapa 2019-2020. Seu objeto de estudo é a realidade social e política que está na base do fenômeno, além de seu correlato jurídico, o que implica relacionar os acontecimentos com a Constituição vigente e com as leis de reforma constitucional que têm sido promulgadas no contexto do processo.

O relato se constrói em torno de oito perguntas ${ }^{4}$, que se referem aos distintos aspectos do processo constituinte.

A metodologia empregada é histórica e bibliográfica, sendo utilizadas como fontes a imprensa digital, páginas da web, artigos publicados em revistas acadêmicas e livros de especialistas na matéria. O propósito é descrever a sequência do processo, sem prejuízo de algumas interpretações sobre o seu sentido político. Este relato é possível porque existe uma história imediata, uma história do Direito e constitucional do tempo presente (PALMA, 2004, 2009, 2012a; VARELA SUANZES-CARPEGNA， 2007，2008，2015; FERNÁNDEZ SARASOLA, 2008, 2009).

Abordaremos a gênese do processo constituinte, o cenário político e social da convocatória do órgão constituinte; a visão dos movimentos sociais sobre as vantagens e limitações do processo em relação às suas demandas; o papel do Direito nesse processo; o sentido de um processo constituinte que culmina com o modelo econômico e com suas demandas; o papel do Direito neste processo; o sentido de um processo constituinte que culmina

\footnotetext{
4 Agradeço aos professores Lucas Machado Fagundes e Enzo Bello pela sugestão das questões a serem abordadas, que estão ligadas aos seus projetos de pesquisa sobre processos constituintes e cidadania na América Latina.
} 
com o modelo econômico neoliberal, ante as reações de forças políticas conservadoras que poderiam desconhecer os direitos sociais, econômicos e culturais consagrados no futuro do texto constitucional; as semelhanças e diferenças em relação ao processo constituinte equatoriano e boliviano e sua luta contra o modelo econômico instaurado por Pinochet; os obstáculos que enfrenta o processo; e, finalmente, o papel dos povos indígenas, negros, mulheres e organizações de trabalhadores.

\section{A demanda por uma Assembleia Constituinte: 1978-2020}

Após o golpe de Estado de 11 de setembro de 1973, a Junta Militar se atribuiu o poder constituinte. Mediante distintos Decretos-leis (normas de nível legal ditadas pelo poder Executivo de fato) foi modificando a Constituição vigente ${ }^{6}$ e, desde o mesmo mês de setembro, impulsionou a ideia de promulgar uma nova Constituição, designando uma comissão de especialistas para este fim.

Um grupo de acadêmicos e políticos opositores do Regime Cívico Militar, organizados sob o nome de Grupo de Estudos Constitucionais ou "Grupo dos 24" exigiu, em 1978, ainda antes de entrar em vigor a dita nova Constituição, que uma assembleia constituinte redigiria uma nova carta fundamental que deveria ser submetida, em seguida, a um plebiscito popular ratificatório. Sua demanda não foi atendida e o regime impôs a Constituição de 1980, que é

\footnotetext{
${ }^{5}$ Veja, para esta temática: Palma e Elgueta (2020), obra que acompanhamos muito de perto neste trabalho.

${ }^{6}$ O Decreto-Lei 788, de 2 de Dezembro de 1974, estabelece o seguinte: "Artigo $1^{\circ}$ - Declara-se que os decretos-lei emitidos até à data pelo Conselho Diretivo, na medida em que sejam contrários, contrários ou diferentes de qualquer preceito da Constituição Política do Estado, tiveram e têm ainda a qualidade de regulamentos de alteração, seja de caráter expresso ou tácito, parcial ou total, do correspondente ao preceito da referida Constituição. Artigo $2^{\circ}$ Clarifica-se o âmbito de aplicação do inciso $2^{\circ}$, alínea o) do artigo $3^{\circ}$, alínea o) do Decreto-Lei 128 de 1973, no sentido de que as alterações à Constituição Política do Estado que devem fazer parte do seu texto e que se entende serem incorporadas a ela, são as alterações de natureza expressa. Artigo $3^{\circ}$ - Os Decretos-lei que venham a ser promulgados no futuro e que possam ser contrários, contraditórios ou diferentes de qualquer norma da Constituição Política do Estado, expressa ou tacitamente, no todo ou em parte, só terão por efeito modificá-la, conforme o caso, se for expressamente explicitamente declarado que a Junta de Governo promulga tal decreto no exercício do seu correspondente Poder Constituinte".
} 
propriamente uma Carta Outorgada (PALMA, 2008), pois violou a soberania nacional e o direito de autodeterminação do povo do Chile ${ }^{7}$.

A demanda por uma assembleia constituinte se manteve no seio da oposição até o início da década de 1980, quando por realismo político se deram os primeiros sinais de se aceitar como um fato a vigência da Constituição da ditadura, ainda que não se aceitasse sua legitimidade (ICHEH, 1985). No ano de 1988, para garantir a transição à democracia, após a derrota eleitoral da candidatura do ditador Augusto Pinochet, os opositores pactuaram a reforma da Carta Outorgada de 1980, enfraquecendo significativamente a exigência do ano de 1978.

A reforma do ano de 1989 mostrou ser insuficiente para as pretensões de uma democracia liberal plena, de modo que a questão constitucional voltou a ganhar relevância no início do século XXI. A aliança governante, Concertación de Partidos por la Democracia, optou por aprofundar a reforma e dar-lhe um caráter refundacional. O então presidente da República, Ricardo Lagos, negociou com a direita que concebeu e apoiou a Carta Outorgada de 1980 (alguns dos líderes juvenis da época ditatorial eram nesse momento senadores ou deputados), reformas que terminavam, segundo sua opinião, com os enclaves autoritários ${ }^{8}$. Inclusive se sustentou que se tratava de uma nova Constituição ${ }^{9}$. Por suas características, chamamos esta nova ordem de Constituição Binominal de 2005 (PALMA, 2008).

\footnotetext{
${ }^{7}$ Grupo de Estudos Constitucionais (1985). Os documentos com declarações do Grupo de Estudos Constitucionais podem ser consultados em: <http://fundacionaylwin.cl/>.

${ }^{8}$ Em agosto de 2005 o Congresso aprovo 58 reformas na Carta Outorgada de 1980 que se caracterizaram como modificações que puseram fim aos enclaves autoritários do texto imposto pela Junta Militar (para todos eles, ver o artigo na estação de rádio Cooperativa de 16 de agosto de 2005 "Lagos afirmou que a reforma da Constituição é 'um dia de alegria" em: <https://www.cooperativa.cl/noticias/pais/politica/reformas-constitucionales/lagos-afirmo-quereforma-a-la-constitucion-supone-un-dia-de-alegria/2005-08-16/125118.html>. Para uma análise deste fenômeno, ver Zúñiga (2005); Diaz de Valdés, José M. (2009).

9 EMOL, 17 de setembro de 2005, "Presidente Lagos firmou Nova Constituição Política" em <https://www.emol.com/noticias/nacional/2005/09/17/195634/presidente-lagos-firmo-nueva-constitucion-

politica.html> e <https://www.emol.com/noticias/nacional/2005/09/17/195634/presidente-lagos-firmo-nuevaconstitucion-politica.html>. Ver Zúñiga (2007, p. 351): "No plano político-institucional, a Constituição Política da República é uma "nova" Carta, uma vez que, com a reforma constitucional de 2005, a transição é formalmente encerrada com a expurgação da Constituição dos seus "enclaves autoritários", do seu estatuto transitório jus fundamental, bem como com da assinatura colocada no texto pelo governante da época, da Junta de Governo e seus ministros. Por outro lado, no campo econômico-social (direitos civis, ordem pública e econômica, constituição econômica e constituição social) a atual constituição é essencialmente a "velha" Carta de 1980, na qual se cristalizaram, principalmente em sua parte dogmática (valores, princípios, direitos fundamentais e garantias), os componentes ideológicos (originariamente autoritários, neoliberais, jusnaturalistas e remotamente corporativistas) de uma refundação autoritária do capitalismo".
} 
Em paralelo e com rejeição a este processo de reforma, foi surgindo um movimento minoritário de resistência ao puro reformismo. Assim se formou no ano de 2002, em distintas escolas de Direito do país, um movimento minoritário, o Movimento por uma Assembleia Constituinte (MOVASAC) e, mais tarde, no ano de 2004, o Movimento Chile à Carta (PALMA, 2004).

Em março de 2006, a Fundação Instituto da Mulher e o Movimento Pró Emancipação da Mulher Chilena (MEMCH) publicaram o livro "Sociedade Civil e nova Constituição: para um pacto cidadão para a Constituição que queremos", no qual se reivindicou a assembleia constituinte (VIVEROS, 2006).

Em julho de 2007 surgiu o movimento "Cidadãos por uma Assembleia Constituinte". No ano de 2008, distintas organizações já impulsionavam a demanda por uma assembleia constituinte e uma nova Constituição, e o Comitê por uma Assembleia Constituinte estava ativo na vida política. Também nestes anos se formou a Rede de estudantes pela assembleia Constituinte.

Na campanha presidencial de 2009, o candidato de centro-esquerda, Frei Ruiz- Tagle, incluiu em seu programa de governo a aprovação de uma nova Constituição. Verificado o primeiro turno, em reunião com o Comitê por uma Assembleia Constituinte, Frei cogitou a possibilidade da convocatória de uma Assembleia Constituinte ${ }^{10}$.

Diferentes organizações da sociedade civil surgiram na segunda década do século XXI promovendo a assembleia constituinte. As mobilizações do ano de 2011 aprofundaram a vinculação das demandas sociais com a iniciativa de nova Constituição.

Em 18 de julho de 2011, um pequeno grupo de parlamentares apresentou na Câmara de Deputados uma proposta de reforma constitucional para estabelecer uma assembleia constituinte (Boletim n ${ }^{\circ}$ 7792-07). Porém, não teve grande impacto.

O Comitê de Iniciativa por uma Assembleia Constituinte promoveu a fórmula da quarta urna eleitoral (imitando a experiência colombiana ${ }^{11}$ ). O propósito era que, conjuntamente com as

\footnotetext{
${ }^{10}$ Para uma reflexão segundo uma perspectiva institucional, veja-se: Couso, Coddou, 2009.

${ }^{11}$ LAUVERGNIER, C.hloé. Quarta Urna: A saída para convocar a uma Assembleia Constituinte no Chile. , El Ciudadano [online], 25 de agosto de 2012. Disponível em: <http://otramerica.com/temas/cuarta-urna-la-salida-paraconvocar-a-una-asamblea-constituyente-en-chile/2322>.
} 
eleições parlamentares e presidenciais, fosse perguntado aos cidadãos se desejavam ou não reformar a atual Constituição através de uma assembleia constituinte. A proposta foi apoiada por alguns senadores e implicou na apresentação, em 04 de setembro de 2012 (Boletim n. 8562-07), de um projeto de reforma constitucional, que não prosperou em definitivo. É interessante lembrar os fundamentos invocados:

Sustentamos que, como consequência de diversas circunstâncias sociais, morais, jurídicas, econômicas e institucionais se formou uma opinião pública consistente, no sentido que convém aos altos interesses do país que o povo soberano proceda a eleger uma Assembleia Constituinte, que tenha como função exclusiva e específica elaborar um novo texto constitucional dotado de uma clara e indiscutível legitimidade de origem, assim como de conteúdos democráticos em todos os âmbitos de sua regulação (PALMA, ELGUETA, 2020).

Ao apresentar a proposta, os dirigentes do Comitê de Iniciativa apontaram:

Hoje quase a totalidade das organizações sociais, sindicais, estudantis e de povos originários, decidiram reclamar a convocatória de uma Assembleia Constituinte e não aceitar que a maioria dos chilenos e chilenas permaneçamos reduzidos à condição de meros consumidores, excluídos do debate e das decisões que concernem aos poderes públicos (PALMA, ELGUETA, 2020).

Pesquisas realizadas no ano de 2013 indicavam que mais de 70\% dos entrevistados eram favoráveis à opção por uma nova Constituição e que $83 \%$ optavam pelo mecanismo da assembleia constituinte. Em dezembro de 2013, outra pesquisa mostrou que $57 \%$ se inclinavam por uma assembleia constituinte convocada pelo Congresso e $23 \%$ por uma convocada pelas próprias organizações sociais. Somente $7 \%$ acreditavam que a nova Constituição deveria ser elaborada pelo Congresso Nacional.

O Fórum da Assembleia Constituinte e a instância do Poder Social Constituinte realizaram ações em prol desta convocação.

No mês de outubro do ano de 2014, um conjunto de organizações não-governamentais publicou a proclamação: "Sem Assembleia Constituinte, não há Nova Constituição. Manifesto poder social constituinte", no qual destacaram, entre outras coisas:

Chamamos - de forma aberta - todas as organizações e movimentos sociais - estudantis, de trabalhadores/as, de moradores/as, de povos originários, de meio ambiente, de diversidade sexual -, e a todas as pessoas que desejem fazer parte de um desafio com vocação transformadora para uma ampla articulação de forças sociais.

Declaramos firmemente e sem ambiguidades: Sem Assembleia Constituinte, Não há Nova Constituição", e que a realização de um processo constituinte se valida 
exclusivamente com a vontade e a soberania popular, e não mediante mecanismos institucionais sem legitimidade cidadã (PALMA, ELGUETA, 2020) ${ }^{12}$.

Em 13 de outubro de 2015, o governo de Bachelet comunicou ao país a decisão de avançar para uma nova Constituição e definir um itinerário a respeito ${ }^{13}$. De acordo com o itinerário proposto, os resultados deveriam ser levados ao Congresso para que se sanasse a questão constitucional no ano de 2017. Somente se cumpriu a primeira parte do processo no tempo planejado ${ }^{14}$. O projeto que reconheceu as bases foi apresentado no último minuto do governo de Bachelet (6 de março de 2018) como projeto de uma nova Constituição e reforma constitucional. Não houve debate. O atual governo descartou a continuidade do debate constitucional e, em 15 de março de 2018, deu por encerrado o processo ${ }^{15}$.

A manifestação contra o aumento da passagem do transporte subterrâneo (metrô), a partir de 07 de outubro de 2019, organizada por estudantes secundaristas, assim como a repressão de que foi objeto o movimento estudantil nas estações do Metrô por parte da polícia (carabineros), transformaram-se em terreno fértil para a manifestação aberta do mal-estar social $^{16}$. As manifestações se mantiveram ao longo das semanas e em 18 de outubro, em meio aos protestos sociais, diversas estações do Metrô foram atacadas e incendiadas. A manifestação nas ruas superou a questão do aumento das passagens e se concentrou na desigualdade e na iniquidade do modelo neoliberal, manifestada na carência da cobertura total do direito à saúde;

\footnotetext{
${ }^{12}$ Para um balanço de uma perspectiva institucional e não de um movimento social, veja-se Soto, 2014.

${ }^{13}$ O Movimento social não alterou sua postura e envia a negativa a iniciativa presidencial por ser pouco participativa e resolutiva, segundo Miguel Santibáñez em artigo publicado em El Desconcierto em abril de 2016, "A sociedade civil lança proposta cidadã para uma Nueva Constituição" em <https://www.eldesconcierto.cl/2016/04/13/lasociedad-civil-lanza-propuesta-ciudadana-para-una-nueva-constitucion/>. O artigo dá conta da emergência da figura dos "Encontros Territoriais com uma metodologia especialmente desenhada e que se coloca à disposição para contribuir no lado do cidadão no processo de construção da Nova Constituição. A iniciativa impulsada pela Associação Chilena de ONG, ACCIÓN, "Práticas Cidadãs para uma Nova Constituição", conta com a colaboração da Escola de Antropologia da Universidade Alberto Hurtado e da Faculdade de Direito da Universidade do Chile". Veja-se também: <http://www.asambleaconstituyente.cl/>.

${ }^{14} \mathrm{O}$ texto recompilatório que preparou Lucas Sierra e Francisco Zúñiga, que deixou testemunho de como estão os diferentes atores de direita, centro e esquerda diante da questão constitucional, resulta de grande valor para conhecer o alcance do debate no seio da institucionalidade (Sierra - 2016-).

${ }^{15}$ El diario de Cooperativa, "Ministro Chadwick: Não queremos avançar no projeto da Nova Constituição" , Jueves, 15 de Marzão de 2018, em: https://www.cooperativa.cl/noticias/pais/politica/reformasconstitucionales/ministro-chadwick-no-queremos-que-avance-el-proyecto-de-nueva/2018-03-15/101725.html

${ }^{16}$ GARCÉS, Bastián. As evasões massivas no metro de Santiago partiram por um meme. El Libero, 18 de outubro de 2019, em <https://ellibero.cl/actualidad/las-evasiones-masivas-en-el-metro-de-santiago-partieron-por-unmeme/>.
} 
na má qualidade da educação pública; nas dificuldades de acesso à moradia própria; nas desigualdades do sistema de seguridade social baseado em seguros privados (Administradoras de Fundos de Pensões, AFP); na exigência de consagrar o direito humano à agua; nas desigualdades de gênero; e na necessidade de contar com uma nova Constituição. O governo respondeu com a declaração do estado de exceção, estado de emergência, o que implicou na saída às ruas do pessoal das forças armadas, por cuja ação morreram várias pessoas ${ }^{17}$. Desde então ${ }^{18}$ há milhares de feridos, centenas de pessoas perderam a visão em decorrência de balas ou bombas de gás lacrimogêneo $^{19}$, e centenas de detidos nos protestos estão no cárcere ${ }^{20}$.

Estamos na presença de um movimento social? Segundo a perspectiva de Salinas (2016) a resposta é positiva: existe uma aliança muito ampla de pessoas, que pertencem ou não a uma organização formal (por exemplo ONG ou uma associação profissional) e que se associam para alcançar uma mudança social. A mesa da Unidade Social representaria parte desse movimento social, mas não o esgota, e expressa esta aliança a que se refere Salinas:

O movimento social tem as seguintes características: a) Expressa uma clara perspectiva de valor (solidariedade versus individualismo egoísta; responsabilidade com o futuro versus utilidade imediata) e interesses econômicos precisos (substituição do regime neoliberal de Estado subsidiário, por um de Estado ativo, participativo e promotor da justiça social); b) Não se formou em torno de um líder carismático, tampouco é liderado por uma vanguarda; c) Tem um componente pluriclassista e logrou fundir demandas de diferentes coletivos como os estudantes, as mulheres, os ecologistas, o movimento dos sem-teto, os defensores do direito humano à água, o movimento pela diversidade sexual, organizações sindicais, organizações de funcionários públicos, associação de professores e incipientes movimentos políticos; d) Os partidos políticos tradicionais que apoiam suas reivindicações não têm presença ativa na ação do movimento devido à resistência de alguns de seus atores em lhes dar visibilidade no processo, que é considerado político, mas não político-partidário; e) Surgimento de iniciativas destinadas à criação de novos partidos políticos, qualificados como instrumentais, que seriam postos ao serviço do movimento social para permitir sua participação no quadro

17 Deutsche Welle DW, Santiago sob estado de emergência trás fortes distúrbios, 19 de outubro, em <https://www.dw.com/es/santiago-bajo-estado-de-emergencia-tras-fuertes-disturbios/a-50896064>.

${ }^{18}$ Uma proposta de cronologia dos fatos podem ser encontrados em Deutsche Welle DW, A cronologia do explosão social de Chile, em <https://www.dw.com/es/la-cronolog\%C3\%ADa-del-estallido-social-de-chile/a-51407726>.

${ }^{19}$ Para conhecer as estatísticas, visitar a página da web do Instituto Nacional de Direito Humanos, em particular, os relatórios do Instituto, em <https://www.indh.cl/bb/wp-content/uploads/2020/03/Reporte-general-18-03-2020-dedatos-sobre-violaciones-a-los-derechos-humanos-v04.pdf>.

${ }^{20}$ Deutsche Welle DW, Chile: denunciam a morte de um manifestante e lesiones a periodista, 8 de março de 2020, em <https://www.dw.com/es/chile-denuncian-la-muerte-de-un-manifestante-y-lesiones-a-periodista/a-52679924>. O Instituto Nacional de Direitos Humanos tem assumido um rol na defesa dos Direitos Humanos de quem participam nas manifestações contra o Governo em exercício de seu Direito de reunião e manifestação, veja-se: <https://www.youtube.com/watch?time_continue=51\&v=Pzph4RsDLDw\&feature=emb_logo $>$. 
institucional constituinte que está sendo criado, e que se dissolveriam assim que termine a conjuntura eleitoral ${ }^{21}$.

As pesquisas publicadas, entre outras entidades, pela Activa Research, o Núcleo de Desenvolvimento Social do Milênio (DESOC) e o Centro de Microdados, em colaboração com o Centro de Estudos de Conflito e Coesão Social (COES) e a Faculdade de Economia da Universidade do Chile - "Termômetro Social 2" -, a pesquisa aplicada pelo Centro de Estudos Públicos (CEP), mostram que uma maioria muito relevante da população chilena apoia os protestos e que o Governo conta com uma adesão muito baixa.

\section{Qual é o cenário político e social da convocatória da Assembleia Nacional Constituinte?}

Temos sustentado desde 2004 (PALMA, 2004) que o livre desenvolvimento do capitalismo no Chile desde 1977 provocaria uma "nova questão social", como a que a sociedade chilena viveu no final do século XIX e nas primeiras décadas do século XXI. O primeiro experimento capitalista burguês liberal chileno, implantado a partir da segunda metade do século XIX, instalou as classes trabalhadoras populares em uma pobreza absoluta. A literatura histórica identifica alguns elementos centrais desta questão social: 1. Uma economia capitalista consolidada e aplicada com pureza. 2 Um processo descontrolado de industrialização e urbanização. 3. Agravamento das más condições de subsistência dos trabalhadores e aprofundamento da acumulação da riqueza, consolidando-se o Estado oligárquico. 4. Controle pela oligarquia dos poderes do Estado. 5. Como consequência, a indiferença dos governos e do Congresso em relação ao sofrimento do povo. 6. O surgimento de uma resposta a partir dos setores populares aos abusos, o que implicou na organização popular na base, bem como na formação de partidos políticos populares. 7) Forte repressão do Estado oligárquico à luta organizada do povo (o Massacre de Santa Maria de 1907 ainda se conserva na consciência histórica do povo).

\footnotetext{
${ }^{21}$ A tese dos novos movimentos sociais apresenta virtudes para procurar compreender o caso chileno, ao contrário dos mais tradicionais, ainda que existam alguns elementos que não se encaixam completamente. Como esta é uma questão diferente desta aqui abordada, remetemos para o texto já citado de Salinas (2016).
} 
A luta contra os abusos a partir da organização popular desembocou em uma crise social e política, que teve seu ponto culminante no ruído de sabres. Em 2 de setembro de 1924, os militares presentes no Congresso Nacional pressionaram a aprovação de leis sociais que terminaram com a regulação liberal das relações de trabalho. Foi aberto um processo que culminou na Constituição de 1925, que defraudou as demandas da Assembleia Constituinte de Empregados e Intelectuais (reunida em Santiago do Chile entre 8 e 11 de março de 1925).

A partir de 1925, pela via legal, as demandas do mundo do trabalho começaram a ser satisfeitas, gestando-se a partir de 1932 o Estado benfeitor ou de bem-estar.

Em 11 de setembro de 1973 se restaurou, pela via ditatorial, o modelo econômico que provocou a questão social e o desmantelamento do Estado de bem-estar social. Como consequência, hoje nos deparamos com um conjunto de fenômenos que remontam àquele período traumático da história nacional: os abusos atuais condenam o mundo do trabalho à pobreza, ao medo e à desesperança. A classe popular e a classe média sofrem com a falta de justiça social. O que se vem construindo nos últimos 47 anos não é uma realidade idêntica à da questão social, mas tem elementos comuns. 1. Uma economia capitalista consolidada e aplicada com pureza. 2. Um descontrolado processo de urbanização que gera especulação imobiliária, moradias indignas para as classes média e popular e cujos preços muitas vezes são impossíveis de se pagar por grande parte da força de trabalho. 3. Como consequência do enfraquecimento do sindicalismo e da negociação coletiva, as relações de trabalho, são determinadas num plano de desigualdade absoluta. 4. Foi produzida uma escandalosa acumulação de riqueza em um grupo minoritário e foi aprofundada a desigualdade. 5. O grande empresariado nacional e estrangeiro tem influência decisiva sobre os poderes do Estado. Como consequência, há indiferença por parte dos governos e do Congresso em relação ao sofrimento do povo devido a serviços deficientes de saúde, educação, seguridade social, habitação etc. O surgimento de uma resposta dos setores populares aos abusos, o que implica organização popular na base e desobediência civil. 7) Forte repressão do Estado à luta organizada do povo (PALMA, 2019).

Como consequência, o cenário político e social é caracterizado por uma grande mobilização em todo o país em demanda de mudanças profundas no modelo neoliberal, com impacto principalmente no plano constitucional e em matéria de direito à seguridade social, direito à saúde, direito à educação (exige-se educação pública, gratuita e não sexista em todos os 
níveis educacionais), direito à moradia e reconhecimento do direito humano à água; exige-se também o reconhecimento constitucional dos povos originários e o respeito aos direitos das minorias sexuais.

A mobilização atingiu uma magnitude muito significativa e uma profunda conexão com a demanda por uma nova Constituição. É assim que os partidos políticos, que por décadas ignoraram a demanda por uma assembleia constituinte, e o governo de direita, que descartou em março de 2018 seguir adiante com o processo constituinte, tiveram que gerar as condições institucionais para a realização de um processo constituinte. Em 15 de novembro de 2019, eles assinaram o chamado Acordo Pela Paz Social e a Nova Constituição, que gerou as leis que institucionalizam o processo constituinte.

Alguns partidos com representação parlamentar, como o Partido Comunista, o Partido Progressista e a Federação Regionalista Social Verde abstiveram-se de assinar tal acordo e o denunciaram como ilegítimo. Em todo caso, sua incidência eleitoral é baixa, mas tem proximidade e conexões com o movimento social.

Como dissemos (PALMA, ELGUETA, 2020), a institucionalidade foi surda por décadas à demanda do povo. Surpreendida e aterrorizada pela vontade de mudanças expressada pelas organizações sociais e pela crescente legitimação do protesto social e do direito à rebelião, construiu uma solução que mostra o interesse em controlar este poder, e não em interpretar completamente as suas demandas. Somente esta perplexidade pode explicar as limitações estabelecidas na lei convocatória para a Convenção encarregada de redigir a Constituição, manifestam o temor ao soberano e, em outros casos, um desconhecimento ou falta de valoração da histórica luta pela assembleia constituinte que tem sido impulsionada pelas organizações sociais.

A Convenção Constitucional será escolhida segundo as regras com as quais se elege a Câmara dos Deputados. Estas regras não favorecem a participação dos independentes e não asseguram a representação dos povos originários, apesar de favorecerem sos partidos políticos e suas alianças, que poderiam acabar controlando a Convenção. Por outro lado, como a obrigatoriedade de votar não é exigida para todo o processo, a abstenção favorecerá as posições mais conservadoras e os partidos tradicionais. O governo se recusou a impulsar que a votação de abril seja obrigatória, assim como os partidos que o apoiam. Existe, portanto, um grande risco de 
que os mesmos partidos que estão deslegitimados, e cuja conduta é uma das causas da mobilização social, acabem controlando a convenção constitucional.

Trata-se de uma autêntica convocatória para assembleia constituinte? A lei que regula a matéria, a Lei n. 21.200, publicada em 24 de dezembro de 2019, substituiu o capítulo XV da Constituição vigente, relativo à reforma da Constituição. A nova normativa não convoca uma assembleia constituinte, mas configura um cenário em que a assembleia é uma possibilidade remota. Com efeito, a lei estabelece que a cidadania deve responder a duas perguntas. Pela primeira, deve decidir se aprova ou rejeita uma nova Constituição. Se a rejeição triunfar, não haverá nenhum processo constituinte ${ }^{22}$.

No que se refere aos efeitos do triunfo da rejeição, os grupos de direita que o promovem, procuram legitimar sua posição afirmando sua disposição para realizar as reformas constitucionais que o país necessite:

a melhor opção para o Chile neste momento é votar não, mas um não propositivo, um não cheio de propostas de reforma à Constituição. Assim, não é um "não" que fecha a porta, mas que nos leva a discutir os conteúdos da Constituição que queremos ${ }^{23}$.

E o que acontece se vencer a aprovação? Neste caso, adquire relevância a segunda pergunta que as cidadãs e os cidadãos deverão responder. Indica a Lei n. 21.200: "Que tipo de órgão deveria redigir a Nova Constituição?”. Devendo escolher o eleitor ou eleitora entre uma “Convenção Constitucional Mista” ou uma "Convenção Constitucional."

A “Convenção Constitucional Mista” estará "Integrada em partes iguais por membros eleitos popularmente e parlamentares em exercício". A “Convenção Constitucional” estará "Integrada por 172 membros, dos quais 86 correspondem a cidadãos eleitos especialmente para estes efeitos e 86 parlamentares que serão eleitos pelo Pleno do Congresso, conformado por todos os senadores e deputados em exercício. Por sua vez, a Convenção Constitucional será

\footnotetext{
${ }^{22}$ Para conhecer alguns argumentos para a rejeição e aprovação, veja-se EMOL, Os argumentos atrás da Aprovação e Rejeição a uma nova Constituição no ano chave para o futuro do Chile, 14 de fevereiro 2020, em $<$ https://www.emol.com/noticias/Nacional/2020/02/14/976576/Plebiscito-2020-constitucion-rechazoapruebo.html>.

${ }^{23}$ A terceira, Jorge Alessandri (UDI) se define por "Rejeição" no plebiscito, Não há necessidade de uma campanha de terror, o terror já está, 10 de janeiro de 2020, em <https://www.latercera.com/la-tercera-pm/noticia/jorgealessandri-udi-se-define-rechazo-plebiscito-no-falta-una-campana-del-terror-terror-ya-esta/969191/> . Claudio Alvarado escreveu em 15 de janeiro 2020 uma coluna interessante sobre como administrar a vitória da rejeição, E se a rejeição vencer? A Constituição e os desafios da direita, em: <https://ciperchile.cl/2020/01/15/y-si-gana-elrechazo-la-constitucion-y-los-desafios-de-la-derecha/>.
} 
composta por 155 pessoas, sob um sistema paritário. A paridade implica igual número de homens e de mulheres como constituintes. Esta paridade só se aplica à Convenção Constitucional (Lei n. 21.216, de 24 de março de 2020).

O Chile terá uma assembleia constituinte? Não se vencer a opção de rechaço a uma nova Constituição. Tampouco se vencer de aprovação e com ela a opção pela Convenção Mista. A possibilidade de que se imponha esta fórmula não é baixa, parte do eleitorado da Renovação Nacional, o partido do presidente Piñera, está apoiando esta fórmula, que certamente será a do eleitorado de centro-direita.

E se vencer a aprovação e a opção pela Convenção Constitucional? A resposta é debatida por políticos e acadêmicos. Uma parte muito significativa dos partidos políticos sustenta que este órgão é uma autêntica assembleia constituinte, porque se trata de um corpo inteiramente eleito que se encarregará de preparar uma nova Constituição. O movimento social, por sua vez, assim como alguns partidos da esquerda, afirmam que dados os obstáculos estabelecidos pela Lei n. 21.200 à soberania da Convenção Constitucional, não seria uma verdadeira assembleia constituinte. De que se tratam ditas limitações? A lei estabeleceu que:

A Convenção deverá aprovar as normas e o regulamento de votação das mesmas por um quórum mínimo de dois terços de seus membros em exercício.

A Convenção não poderá alterar o quórum mínimo nem procedimentos para seu funcionamento e para a adoção de acordos.

A Convecção não poderá intervir nem exercer nenhuma outra função ou atribuição de outros órgãos ou autoridades estabelecidas nesta Constituição ou nas leis.

O texto da Nova Constituição que se submeta o plebiscito deverá respeitar o caráter de República do Estado do Chile, seu regime democrático, as sentenças judiciais finais e executadas e os tratados internacionais ratificados pelo Chile e que se encontrem vigentes.

Poderá reclamar de uma infração às regras de procedimento aplicáveis à Convenção, contidas nesta epígrafe, e daquelas de procedimento que emanem dos acordos de caráter geral da própria Convenção. Em nenhum caso se poderá reclamar sobre o conteúdo dos textos que em elaboração. Conhecerão esta reclamação cinco ministros da Corte Suprema, escolhidos por sorteio pelo mesmo Tribunal para cada questão levantada. A reclamação deverá ser subscrita por ao menos um quarto dos membros em exercício da Convenção e será interposta à Corte Suprema, no prazo de cinco dias a contar da data em que se tomou conhecimento do vício alegado. A reclamação deverá indicar o vício reclamado, que deverá ser essencial, e o prejuízo que causa.

O órgão Convenção Constitucional não seria uma assembleia constituinte. Por que? Porque não basta a característica de que seus membros sejam eleitos/as. A assembleia é uma manifestação do poder constituinte originário, conformada como uma reunião de cidadãs e 
cidadãos que, eleitos democraticamente em eleições livres e participativas, assumem a tarefa de debater e elaborar um texto constitucional que se submete a aprovação do povo soberano mediante plebiscito ou referendo. Corresponde à própria organizar seu trabalho, assim como determinar o quórum para adotar seus acordos. Sua única tarefa é elaborar o texto constitucional que será plebiscitado, devendo fazê-lo dentro do tempo fixado pela sua convocatória. Dissolvese no momento em que é promulgado o decreto que convoca o plebiscito.

No caso da Convenção Constitucional, um poder constituído, como o do Congresso Nacional, fixou as regras de formação de sua vontade. Assim, o poder constituído se transformou em um poder superior ao da Convenção, à qual se proíbe modificar ditas regras e, inclusive, se obriga a respeitar determinados mandamentos jurídicos que claramente são de nível infraconstitucional. Inclusive, a Convenção pode ser questionada em alguns aspectos de seu trabalho através de uma ação interposta perante a Corte Suprema. Este órgão pode ser qualificado como Assembleia Constituinte? Não. No Chile foi convocada uma assembleia constituinte que redija uma nova Constituição? Parece-nos que não.

A Mesa de Unidade Social, que expressa em boa medida as demandas do movimento social, rejeita a assimilação entre Convenção Constitucional e Assembleia Constituinte, denominando a sua proposta de "Assembleia Constituinte Livre, Soberana, Paritária e Plurinacional"24.

Isto significa que não será possível realizar uma assembleia constituinte? Para responder esta questão, deve-se ter em conta o contexto de geração da Lei n. 21.200 e da Lei n. 21.216. Elas não estavam na agenda do atual Presidente da República. Não faziam parte do seu Programa de Governo. Então, porque se convocou este plebiscito e esta eleição? Porque o movimento pela assembleia constituinte, que existe desde 2002, somado ao movimento social mais relevante da história chilena do século XXI, impôs a convocatória de uma assembleia constituinte como solução para a crise social e política na qual o país se encontra.

\footnotetext{
${ }^{24}$ Ver o documento da mesa de Unidade Social, Uma Nova Constituição via Assembleia Constituinte. Aspectos básicos para uma assembleia democrática, livre, soberana, paritária e plurinacional, em <https://www.colegiodeprofesores.cl/2019/12/04/propuesta-unidad-social-una-nueva-constitucion-via-asambleaconstituyente/>.
} 
Os partidos políticos com representação parlamentar acordaram uma fórmula que não responde totalmente à demanda do movimento social. A indiferença dos partidos políticos diante desta exigência da sociedade civil é uma característica da transição chilena desde a ditadura à democracia. Enquanto no passado os partidos políticos puderam resistir à ação do movimento social que exigia mudanças profundas, nesta ocasião foi impossível. Em 25 de outubro de 2019, aconteceu em Santiago a marcha mais numerosa da história republicana chilena, que foi replicada em todo país ${ }^{25}$. Nela, milhões de pessoas exigiram profundas transformações econômicas e uma nova Constituição via assembleia constituinte. Este fenômeno e uma aprovação nas pesquisas dos partidos de apenas $2 \%$, e do governo de um paupérrimo $6 \%$, forçaram a institucionalidade a dar esse sinal de abertura para debater a demanda do povo. No entanto, os atores políticos institucionalizados tentaram controlar estas exigências, pois temem que o movimento social logre uma representação suficiente que lhe permita controlar a Convenção; por fim, desenharam uma Convenção quase manietada. Nessa linha de ação, a Lei n. 21.216 regulou a participação dos independentes, fórmula que promove o movimento social, obstaculizando suas candidaturas ao exigir-lhes um número de assinaturas de apoiadores, o que resultará difícil de se alcançar por aqueles que carecem de uma organização que os apoie.

Alguns dos partidos que assinam o acordo político que permitiu que surgisse a Lei $\mathrm{n}$. 21.200, como o Partido Socialista ${ }^{26}$ e o Partido Revolução Democrática ${ }^{27}$, insistem em qualificar como assembleia constituinte a Convenção Constitucional, não se responsabilizando pelas severas limitações que tem seu poder constituinte ${ }^{28}$.

\footnotetext{
${ }^{25}$ El Mostrador, Mais de 1,2 milhões de pessoas em Santiago e milhares em outras regiões deram o sinal político mais forte desde o NÃO, em <https://www.elmostrador.cl/noticias/pais/2019/10/25/convocan-a-la-marcha-masgrande-de-chile-para-este-viernes-en-plaza-italia/>.

${ }^{26} \mathrm{O}$ documento do órgão oficial do Partido, o Instituto Igualdade, que aborda aspectos do processo tem por título "Proposta para a discussão Constitucional do Partido Socialista de Chile: havia uma Nova Constituição elaborada na democracia, mediante uma assembleia constituinte", versão digital em <https://institutoigualdad.cl/2020/03/09/propuesta-para-la-discusion-constitucional-del-partido-socialista-de-chile/>. ${ }^{27}$ El Dinamo [eletrônico], Deputado RD corrige a prefeito Jorge Sharp: Convenção Constitucional é o mesmo que Assembleia Constituente, em <https://www.eldinamo.com/nacional/2019/12/16/diputado-rd-pablo-vidal-alcaldesharp-convencion-constitucional-ac/>.

${ }^{28}$ Um olhar sobre o debate num artigo de imprensa: VARGAS, Felipe. Conceito de convenção constitucional: A discussão que divide a esquerda diante do processo constitucional. El Mercurio [eletrônico]. Disponível em: <https://www.emol.com/noticias/Nacional/2019/12/17/970690/Constitucion-FA <https://www.emol.com/noticias/Nacional/2019/12/17/970690/Constitucion-FA-PC.html>.

PC.html>;
} 
A fórmula dos partidos políticos recebeu o apoio de um número muito importante de professores de Direito Constitucional mediante uma carta aberta ao país intitulada " $\mathrm{O}$ Acordo pela Paz Social e a Nova Constituição' não é uma armadilha”. No entanto, paralelamente, foi rejeitado pela mesa da Unidade Social $^{29}$.

Mas se os atores políticos chamam esta convenção de assembleia constituinte, é possível que funcione como tal? Cabe resgatar que o Presidente da República, no discurso de promulgação da Lei n. 21.200, qualificou a Convenção como assembleia constituinte. Também, que a mesma lei qualifica os integrantes como "constituintes convencionais". Considerando que estamos frente a um caso típico de estreita ligação entre política e direito, acreditamos ser possível que a política gere um contexto de reafirmação do exercício do poder constituinte originário. Isto dependerá, como se depreende da Lei n. 21.200, do quórum alcançado pelos partidos políticos e grupos que tratam a convenção como assembleia constituinte. Como poderiam fazê-lo sem violar o claro mandato da lei? As regras limitadoras do poder constituinte originário são válidas e legítimas? Trata-se de um importante problema jurídico que deverá ser abordado no momento devido.

4. Como os movimentos sociais veem as possibilidades para a realização futura das demandas socioeconômicas e para a igualdade material para o povo chileno, considerando que a Constituição será aplicada, seguramente, por membros de oligarquias e comprometidos com o sistema econômico capitalista?

A pergunta se refere à principal questão política dessa convocatória: considerando as limitações da convenção e as dificuldades que se configuraram para a participação de independentes, serão aprovadas por este órgão as profundas transformações que exige o povo do Chile? Se não está garantida uma orientação da Convenção para a satisfação das demandas do movimento social, é conveniente participar? Não será mais adequado chamar a abstenção e não legitimar esse processo? Não será mais pertinente realizar um processo paralelo, fora do campo

\footnotetext{
${ }^{29}$ Unidade Social, "Declaração de Unidade Social de rejeição ao Acordo de paz e Nova Constitucional", 16 novembro de 2019, em: <https://unidadsocial.cl/ad/>.
} 
da lei, que, com uma clara identidade de classe, geste uma autêntica Constituição popular? Este debate teve lugar nas chamadas assembleias territoriais, organizações de base comunal definidas por um território ${ }^{30}$. Um pequeno grupo delas está chamando a abstenção, portanto, procurarão aprofundar a via não institucional e a redação de uma constituição fora do marco das Leis n. 21.200 e n. $21.216^{31}$.

Existe outra perspectiva dentro do movimento social, que tende a ser majoritária e que defende participar do processo apesar de suas limitações. Várias razões existem para isso: 1. A composição da convenção está aberta, apenas se conhecerá seu caráter ao contar os votos das distintas alianças eleitorais que disputam seu controle. Trata-se de uma batalha eleitoral sem resultado predeterminado. Nesta medida, o desafio do movimento social é transformar sua energia em votação. Se foram milhões os que se manifestam nas ruas, milhões devem ser os votos para aqueles que sustentem as demandas e as ideias do movimento social. Dado que a questão da composição está aberta, o responsável é participar ativamente da disputa eleitoral. 2. As limitações relativas a quórum e conteúdo normativo jurídico não são aplicáveis a um autêntico poder constituinte originário. Que a Convenção Constitucional se comporte como tal é uma questão política que está estritamente relacionada com os votos que possa somar o movimento social na Convenção. 3. Se a Convenção Constitucional resulta o órgão que deva preparar a nova Constituição, estará integrada de modo paritário, o que permite presumir que o poder eleitoral das mulheres poderia ser decisivo para gerar um texto que responda amplamente às demandas do movimento social. 4. Cabe não perder de vista que a convenção, qualquer seja sua forma e seu caráter, ou não, de assembleia constituinte, não aprovará a nova Constituição. A ela apenas cabe aprovar um texto que apresentará ao povo do Chile para que o aprove ou rejeite

\footnotetext{
${ }^{30}$ A coordenação se denomina Coordenadora de Assembleias Territoriais - CAT. Afirma em seu documento de constituição: "Acreditamos que a Coordenadora debe adotar e fortalecer o Desenvolvimento e autonomia das assembleias, articular a mobilização, unir nossas demandas desde o local até o nacional e avançar para uma Assembleia Popular Constituinte para que uma mudança no Chile responda ao mais amplo protagonismo popular" (o destaque no texto está em <http://www.asambleasterritoriales.org/>). SEGOVIA, Macarena. A la izquierda del acuerdo del 15 de noviembre: la ruta constituyente de organizaciones sociales y territoriales. El Mostrador [eletrônico], 11 de fevereiro 2020. Disponível em <https://www.elmostrador.cl/noticias/pais/2020/02/11/a-laizquierda-del-acuerdo-del-15-de-noviembre-la-ruta-constituyente-de-organizaciones-sociales-y-territoriales/> .

${ }^{31}$ Ver declaração de 18 de janeiro de 2020, em <http://www.asambleasterritoriales.org/que-es-la-cat/declaracioncat/>.
} 
mediante o mecanismo do plebiscito. Isto quer dizer que se não se obtém pelo movimento social que a convenção seja encarregada das profundas mudanças que demanda (porque a integração acabou favorecendo as forças políticas tradicionais a partir do desenho que elas mesmas fizeram), poderá rejeitar o texto no plebiscito respectivo.

Fica em pé uma importante pergunta: se o movimento social rejeita a proposta de nova Constituição, o que acontecerá com a Constituição vigente? Trata-se de uma questão transcendente. A resposta exige não perder de vista a dimensão política e jurídica do fenômeno. Do ponto de vista político, a instalação da Convenção teve lugar porque se aprovou pelo povo ter uma nova Constituição. Como consequência, a Carta Outorgada vigente havia perdido legitimidade. Por outra parte, a rejeição à proposta de Constituição da Convenção geraria o seguinte fenômeno: a Constituição vigente (Carta Outorgada de 1980) não teria legitimidade, porque o país preferiu uma nova Constituição, e a nova não teria sido aceita pela população. $\mathrm{O}$ que se deve fazer? Juridicamente seguirá vigente a Carta Outorgada, ela será o texto constitucional válido, porém, não terá nenhuma legitimidade. Como se administra esse fenômeno? O Presidente da República e o Parlamento deverão optar por relegitimar a Carta Outorgada de 1980 ou abrir um novo processo constitucional. Se estas instituições expressam a direita política e o centro político, seguramente se optará pela relegitimação; pelo contrário, se a presidência e o Parlamento estão controlados pela esquerda e centro-esquerda, será aberto um novo ciclo constituinte.

Como se aprecia, o cenário futuro será resultado de um vibrante processo de construção que avança por caminhos nem sempre coincidentes.

\section{Qual é a importância da lei e de uma Constituição em um processo político de mudanças sociais e econômicas?}

Como já escrevemos (PALMA, 2016), o povo do Chile vem se politizando em paralelo à crise dos poderes representativos: as ruas vibram com o cântico "Oh, Chile acordou, acordou, Chile acordou". Um movimento pluriclassista canta nas ruas "o povo unido jamais será 
vencido", dando a este cântico um novo sentido político ${ }^{32}$. As enquetes apontam que em todos os setores sociais existe um contundente apoio à mobilização (superior a 80\%), assim como às demandas. O canto foi escutado em todos os rincões do país e em todos os setores sociais. Jovens e famílias dos bairros mais abastados, assim como dos mais pobres, aprofundaram com este grito a politização de nossa sociedade. A grande maioria da população chilena esta assumindo a responsabilidade de construir seu futuro. Para isso, o povo despojou de legitimidade o sistema institucional e a Constituição que nos rege, exigindo com total claridade uma transformação profunda do sistema que ela consagra (COUSO, 2019). O modelo neoliberal está em uma profunda crise. As palavras "nova Constituição, assembleia constituinte" aparecem disseminadas em meio ao povo em movimento.

A validade da convocatória e a instalação de uma assembleia constituinte se baseia na soberania e no direito de livre determinação do povo do Chile (autodeterminação na Carta da ONU), estabelecido no Pacto Internacional de Direitos Civis e Políticos: “Artigo 1. 1. Todos os povos têm direito de livre determinação. Em virtude desse direito estabelecem livremente sua condição política e proverem seu desenvolvimento econômico, social e cultural”. Dado que a Carta Outorgada de 1980 deriva de um golpe de Estado, fica evidente que a atual ordem constitucional segue sendo, não obstante suas reformas, um atentado contra o direito de livre determinação. Vício jurídico que não admite convalidação porque seguimos sendo um Estado soberano reconhecido como tal no contexto internacional.

É precisamente o exercício desse direito que faz da assembleia constituinte um exercício de soberania institucional, legítimo e absolutamente respeitoso da ordem jurídica política imperante no Chile: a vigência do Pacto Internacional de Direitos Civis e Políticos em nosso país dá legalidade e legitimidade a esta fórmula.

Por que avançar para uma nova ordem constitucional? Porque a ordem ditatorial e suas reformas estão esgotados. Não geram consenso, mas um profundo mal-estar.

Neste processo o direito pode desempenhar um papel transcendente na medida em que não há uma grave ruptura institucional, não houve um golpe de Estado, mas uma situação de

\footnotetext{
32 O hino "O povo unido jamais será vencido" foi cantado pelas forças populares que apoiavam o governo de 1971 da Unidade Popular (1970-1973), derrotado pelo golpe de Estado de 11 de setembro.
} 
rompimento da ordem pública e de desobediência civil, fenômenos que se tenta conduzir por amplos setores via canais institucionais.

O Direito e a política estão mostrando um papel importante como instrumentos de controle social. As forças políticas que o usam como tal não respondem cabalmente às demandas do movimento social. O divórcio que se vem denunciando desde o princípio do século XXI não conseguiu superar-se nesta conjuntura.

Um setor da população, como vimos, desconfia profundamente deste Direito e desta política, e denuncia que estão a serviço do modelo econômico neoliberal e das forças do empresariado nacional e estrangeiro. As graves denúncias de captura de certos partidos e determinados políticos pelo grande empresariado, que implicdescoavam que suas votações fossem dirigidas pelas gerências empresariais, avalizam esta nfiaanç ${ }^{33}$. Do tipo de órgão que redija a Constituição e da composição do referido órgão (Convenção Mista ou Convenção Constitucional), dependerá se o Direito desempenhará, ou não, um papel de instrumento de mudança social a serviço do povo do Chile.

A academia também está convocada para desempenhar um papel relevante, no entanto, a maioria dos professores de Direito Constitucional se inclina pela fórmula proposta pelo Congresso. Fórmula que não responde, como vimos, às demandas do movimento social.

Se a proposta não institucional de algumas das assembleias territoriais prosperará, isto é, se se chegará a redigir uma Constituição paralela com um grande componente de classe e fora do marco legal estabelecido pelas Leis n. 21.200 e n. 21.216, a busca pela imposição da dita carta constitucional será um fato político que tensionará o Direito, provocando desempenhe um papel como instrumento de controle e repressão social a serviço dos poderes estabelecidos.

Como vemos, política e Direito estão imbricados. Os resultados eleitorais, que fixarão a correlação de forças na ação criadora do Direito, incidirão de modo que o Direito contribua para a mudança social ou que sirva para o controle social e a repressão da dissidência.

\footnotetext{
${ }^{33}$ A imprensa deu ampla cobertura a estas acusações, ver: <http://www.gamba.cl/2018/03/ley-longueira-la-largalista-de-politicos-sobornados-por-las-empresas-pesqueras/>; $\quad<$ https://ciperchile.cl/2015/05/28/ley-de-pesca-pagosilicitos-a-parlamentarios-no-seran-investigados-por-la-fao/>; $\quad<$ https://ciperchile.cl/2018/06/07/nuevas-pruebas-deaportes-ilegales-de-las-pesqueras-a-los-diputados-sauerbaum-y-bobadilla/>;

$<$ https://ciperchile.cl/2018/06/07/nuevas-pruebas-de-aportes-ilegales-de-las-pesqueras-a-los-diputados-sauerbaumy-bobadilla/>; <https://www.latercera.com/noticia/el-mapa-politico-de-los-pagos-de-sqm/>.
} 
Cabe ter presente que em 26 de março de 2020 entrou em vigor a Lei n. 21.221, que, em atenção à pandemia do Coronavírus, modificou as datas de todo o processo e estabeleceu que o plebiscito de 26 de abril de 2020 deverá ser realizado em 25 de outubro de 2020. As eleições de constituintes convencionais, se houver, serão realizadas em 11 de abril de 2021.

\section{Por que fazer uma assembleia constituinte se já se sabe que a futura Constituição, por mais progressista que seja, pode ser violada na prática com o esvaziamento dos direitos sociais e, inclusive, com um golpe de Estado, como no caso da Bolívia?}

Dado que a ineficácia e a violação do Direito é um fenômeno que afeta todo o ordenamento jurídico - por exemplo, o penal - esta possibilidade de violação não é um impedimento para aprovar uma nova ordem constitucional. No entanto, a pergunta tem importância do ponto de vista da cultura constitucional, e a maior ou menor adesão do povo do Chile ao processo constituinte e à nova Constituição. Se os operadores do Direito e os agentes políticos resultam impactados por essa nova cultura constitucional, a possibilidade de vigência da nova carta fundamental será maior. Se não houver adesão popular majoritária à nova ordem constitucional, a defesa da nova ordem de coisas será um assunto de enorme complexidade. Nesse sentido, a capacidade de mobilização mostrada pelo povo do Chile em 25 de outubro de 2019, qualificada como a marcha mais numerosa da história do Chile ${ }^{34}$, será uma barreira importante que deverá ultrapassar aqueles que queiram violar o texto. Um setor minoritário desse vasto mundo de classe média e popular, a chamada primeira linha, mostrou certa capacidade de desobediência civil que pode ser aprofundada em defesa da nova cultura constitucional ${ }^{35}$.

\footnotetext{
${ }^{34}$ El Desconcierto, Os históricos registros que deixou a Maior Marcha do Chile, 25 de outubro de 2019, em <https://www.eldesconcierto.cl/2019/10/25/los-historicos-registros-que-dejo-la-marcha-mas-grande-de-chile/>.

${ }^{35}$ Para uma aproximação às características da chama primeira linha, ver, entre outros FERNANDEZ, Roberto. Qué es y qué expresa la Primera Línea. Disponível em <https://www.eldesconcierto.cl/2019/12/20/que-es-y-que-expresala-primera-linea/>; CÁCERES, Camilo, Crónica sobre la "Primera Línea" de las manifestaciones: Una batalla de David contra Goliat. Disponível em <https://www.theclinic.cl/2019/11/19/cronica-sobre-la-primera-linea-de-lasmanifestaciones-una-batalla-de-david-contra-goliat/> e <http://www.laizquierdadiario.cl/PrimeraLinea-es-tendenciaen-las-redes-sociales-Quienes-son-y-por-que-luchan>.
} 
Neste caso, novamente a política mostra suas profundas conexões com o Direito Constitucional: se não existe uma força política mobilizada em torno da vigência efetiva da ordem constitucional que o povo aprovou soberanamente no plebiscito, sempre será possível que as forças conservadoras e golpistas se alcem para reestabelecer o modelo neoliberal que instalaram em 1980.

\section{O constituinte pretende mudar o modelo econômico instaurado a partir do golpe de Estado do general Augusto Pinochet?}

Todas e cada uma das demandas do "povo unido e acordado" são fruto de uma muito má avaliação dos frutos do modelo neoliberal e dos abusos e arbitrariedades que o caracterizam em sua aplicação. A desigualdade e discriminação que acompanharam o modelo, desde 1977, se desnudaram completamente ao começar se a aplicar o modelo privado de seguridade social. As Administradoras de Fundos de Pensões (AFP), e suas pensões paupérrimas, estão provocando dificuldades na manutenção da qualidade de vida pela classe média, condenando-a ao retorno ao mundo popular de onde saiu com os créditos que pagou ao longo de sua vida laboral. As miseráveis pensões, a má qualidade da saúde, o lucro com os direitos sociais e econômicos golpeiam as idosas e os idosos que se aposentam pelo sistema AFP. A população está rechaçando o modelo de Estado subsidiário, que deixa aos privados total liberdade na atividade econômica, sendo parte significativa desta atividade lucrativa a provisão de saúde, habitação, educação, aposentadorias, assim como de água, eletricidade, transporte e todo o sistema de estradas do país.

A mesa de Unidade Social apresentou ao país a chamada "Agenda social para destravar o conflito e introduzir reformas relevantes ao modelo neoliberal". Nela se exige, entre outras questões:

1. Substituição do sistema de AFP por um autêntico sistema de seguridade social, de maneira tal que os trabalhadores que ingressem no campo laboral no ano de 2030 possam depositar suas economias em um fundo de distribuição...

4. Regulação do trabalho que se realiza em vinculação com a plataforma digital, terminando com a absoluta flexibilidade laboral que impera nesse sistema...

5. Determinação da linha de pobreza em um indicador que seja efetivamente digno, isto é, que esteja de acordo com o custo de vida. 
6. Geração de uma política estatal que assuma a pobreza da população da terceira idade como um problema do país.

7. Fortalecimento da organização sindical e estabelecimento de mecanismo tripartite de negociação (trabalhador, empregador e Estado).

8. Fortalecimento das PYMES e do empreendimento privado, garantindo deste modo o emprego da maior parte da população.

9. Prioridade no desenvolvimento de uma saúde estatal de qualidade: se investirá com preferência nos hospitais públicos e se deixará de subsidiar as Isapres.

10. Prioridade no desenvolvimento de uma educação para maternidade, escolar e universitária estatal de qualidade: se garantirá um gasto público relevante neste sistema educacional e se deixará de subsidiar a educação privada que lucra.

11. Retorno para o Estado da propriedade e controle dos recursos naturais estratégicos para o desenvolvimento do país, garantindo que essa riqueza será investida em seguridade social, saúde e educação.

12. Retorno à propriedade estatal da a água. Fim da especulação e garantia de que todo produtor agrícola e toda população tenham acesso à água como direito.

15. Revisão do sistema de concessões e não renovação das concessões de estradas, portos e aeroportos para o futuro: se formarão empresas mistas com capitais estatais e privados, em que o Estado tenha a propriedade de $51 \%$ das ações.

16. Revisão dos Tratados de Livre Comércio que afetem a soberania produtiva do país.

17. Garantia que os projetos de mineração não ponham em risco a riqueza do meio ambiente do país.

18. Geração de uma política estatal que assuma como um problema relevante e como ameaça para o desenvolvimento do país a mudança climática.

19. Ratificação pelo Estado do Chile do Protocolo Facultativo dos Direitos Sociais, Econômicos e Culturais... Logo, passo à solução de fundo: novo pacto social via assembleia constituinte e plebiscito ratificatório. ${ }^{36}$

É possível apresentar, de grosso modo, as demandas sociais e seu correlato constitucional. Identificar estas temáticas e institutos jurídicos associados a elas não implica que estas terminem sendo as características da nova ordem constitucional. Dado que a Convenção será um espaço em que se encontrarão distintas forças políticas, cada uma dotada de um corpo de valores e interesses, de uma cultura política e constitucional, serão as votações no seio da Convenção as que definirão o ordenamento constitucional que se termine apresentando ao país para que o aprove ou rejeite no plebiscito respectivo.

Sem a pretensão de aprofundar cada tema e de modo meramente exemplificativo, o debate constitucional terá a ver, necessariamente, como temos dito (PALMA, ELGUETA, 2020), com a mudança climática; a revolução digital; a automação; a globalização; a multiporalidade e crise de hegemonia de centros de poder mundiais; o fenômeno da emigração e imigração; a

${ }^{36}$ Documento da Unidade Social em <http://unidadsocial.cl/wp-content/uploads/2020/03/Declaraci\%C3\%B3nBloque-Territorial.pdf >. 
pobreza; o modelo econômico extrativista; assim como com os valores do pacifismo; do humanismo; do laicismo; do feminismo; e, muito importante, do desenvolvimento do Direito Internacional dos Direitos Humanos.

Os debates e traços de um novo constitucionalismo se relacionarão, provavelmente, com as forças que poderiam ser invocadas no processo e participar na Convenção, com os seguintes tópicos (PALMA, ELGUETA, 2020):

- Estado nação, Estado multicultural, Estado plurinacional / - Declarações de direitos amplas ou restritivas, com garantias ou sem garantias / - Estado passivo subsidiário, Estado ativo / - Estado de livre mercado neoliberal, economia social de mercado, economia da solidariedade e da responsabilidade / - Direito de propriedade reforçado em perspectiva tradicional ou com uma função social que considere o interesse geral / - Estado e sociedade civil consumidores ou criadores de novas tecnologias / - Cidadania masculinizada ou cidadania de igualdade de gênero / - Cidadania proprietária ou cidadania igualitária / -Democracia representativa, democracia semidireta, democracia direta / - Estado centralizador, Estado regionalista, Estado autônomo / Estado de Executivo centralizador, Estado de comunas com autonomia e formas de democracia direta / - Regime de governo presidencialista, parlamentar ou semipresidencial / - Regime bicameral ou unicameral / -Controle de Constitucionalidade via Tribunal Constitucional ou via Poder Judiciário/ -Tribunal Constitucional de base democrática ou com déficit de representação; de poderes limitados que não afetem o princípio democrático de produção da lei, ou de poderes abrangentes; com ministros responsáveis ou irresponsáveis perante o Congresso por violação à Constituição.

- Eficácia direta ou mediada pelo aparato político institucional do Direito Internacional dos Direitos Humanos / - Relação entre poder civil e estamento militar, papel das forças armadas e da polícia na nova ordem constitucional.

- Regulação do Poder Judiciário como Administração de Justiça mantendo os mecanismos tradicionais de organização ou como autêntico poder independente, tanto externa como internamente / - Constituição orientada para o passado, Constituição focada no futuro e nos problemas que já têm gerado as mudanças climáticas, a automatização, a inteligência artificial, a revolução digital, a engenharia genética, a robotização e seu impacto na ideia de pessoa. 
Sem pretensão de esgotar as distintas regulações que poderiam ser parte da nova Constituição, pode-se assinalar alguns traços à luz do debate nacional (PALMA, ELGUETA, 2020):

1. Reiteração e melhoramento do catálogo de direitos civis e políticos. Incorporação de mecanismos de democracia direta como iniciativa popular de lei; referendo revogatório; plebiscito como forma regular de consulta ao povo; transferência de recursos e poderes de órgãos regionais ou nacionais aos municípios. Estabelecimento de um regime democrático participativo. Isso implica em formas diretas de participação do povo, seja reconhecendo sua capacidade de apresentar propostas de criação de leis, revogando certo mandato popular, exigindo plebiscito para decidir matérias de alcance geral ou admitindo a questão legal ou constitucional.

2. Ampliação do catálogo de direitos: generalização e especificação de direitos (do adulto maior, da criança etc.) e versões extensas de direitos sociais, econômicos e culturais. Junto aos tradicionais direitos individuais se consagram direitos coletivos.

Uma Constituição que ampare os direitos reconhecidos na ordem jurídica internacional, que promova a organização sindical e o cooperativismo e respeite as organizações de grêmios dos empresários.

Uma Constituição que aborde com enfoque de direitos os processos naturais, científicos e tecnológicos que estão mudando de modo radical e, em algumas ocasiões negativamente, a relação pessoa/natureza, a relação pessoa/máquina e a relação entre as pessoas.

3. Estabelecimento de um poder judicial cuja independência, tanto externa como interna, esteja garantida.

Uma Constituição que fortaleça o acesso à justiça efetiva dos distintos setores da sociedade e, em particular, dos setores populares, de maneira tal que sua atuação nos tribunais e perante os entes administrativos não dependa da capacidade de pagar pelos serviços de profissionais, advogados ou de profissionais vinculados ao mundo do Direito. O Estado deve garantir que toda a pessoa conte com um advogado que a represente na defesa de seus direitos.

4. Incorporação de uma declaração expressa a favor de uma igualdade material básica de oportunidades, colocando em um mesmo plano a liberdade e a igualdade. 
5. Estabelecimento de instrumentos eficazes em matéria de proteção de direitos: defensor do povo, maior catálogo de ações constitucionais, aceitação da jurisdição internacional em matéria de direitos humanos.

6. Declaração expressa a favor da igualdade de sexos e respeito à diversidade sexual.

7. Estabelecimento de um catálogo de deveres constitucionais do cidadão/cidadã. Formação escolar para a cidadania e fomento da cultura humanitária e democrática.

8. Reconhecimento da presença sociocultural, econômica e política da população indígena.

9. Reconhecimento do caráter vinculante do direito indígena e seus mecanismos ancestrais de execução e validação (direito consuetudinário administrado por juízes indígenas, segundo as formas de justiça indígena).

As práticas políticas e jurídicas indígenas têm um limite nas declarações de direitos contidas na mesma Constituição e que velam pela integridade do indivíduo (contra a desigualdade e as práticas de violência e discriminação por razão de sexo e de idade) e do território estatal.

11. Como consequência da presença das comunidades indígenas, a consagração de um Estado Plurinacional.

12. Como consequência da presença indígena, a consagração do Estado Pluricultural.

13. Estabelecimento da fórmula do Estado regional. Altos graus de descentralização e autonomia: fortalecimento do poder regional e participação comunal.

14. Fomento à participação política sob a forma de partidos, organizações ou movimentos.

15. Devida representação da diversidade do país em instâncias decisivas, como o Tribunal Constitucional, que deve ser reformado em suas composição e atribuições.

16. Banco Central obrigado a zelar para que as decisões econômicas atendam a soberania econômica do país em um contexto de economia para a solidariedade e a responsabilidade.

17. Forte investimento estatal em investigação em ciência e tecnologias, postas a serviço do país e da humanidade. 
18. Estabelecimento de novas categorias jurídicas destinadas a resolver o problema ecológico: reconhecimento da dimensão política cidadã da questão ecológica.

19. Estabelecimento de limites ao poder das transnacionais: geopolítica econômica (controle dos recursos naturais).

20. Soberania efetiva sobre os recursos naturais estratégicos para garantir o bem-estar material do país e seu desenvolvimento sustentável, podendo desenvolver formas de propriedade mista com capitais privados, mas com maioria acionária sob controle estatal.

Novo tratamento jurídico da natureza e dos animais: adequação da visão andina da relação do ser humano com a natureza de acordo com os desafios que trazem consigo as mudanças climáticas.

Consagração constitucional do direito humano à água.

21. Normas sobre acesso à informação pública, transparência e combate à corrupção pública.

22. Garantia de que o desenvolvimento tecnológico esteja acessível e a serviço das grandes maiorias.

23. Consagração de um sistema de Administração Pública eficiente (confiança na gestão estatal) e a serviço efetivo dos habitantes e da atividade empresarial privada (respeito à iniciativa privada): mecanismos de controle cidadão da gestão pública.

24. Consagração da possiblidade do Estado empresário e da empresa mista (capitais privados e estatais com maioria estatal) e uma economia da solidariedade e responsabilidade com as gerações futuras.

25. Promova a pequena e média empresa privada sob a modalidade de empresa B.

26. Fomente a solidariedade entre os povos do mundo e promova a solução pacífica dos conflitos.

27. Situe a população nacional num contexto novo: o da humanidade no início de um processo de crise planetária. Portanto, promova a busca de soluções globais velando pela democratização das instâncias internacionais.

28. Reorganize o poder político institucional, estabelecendo um sistema unicameral. Carece de sentido nos tempos atuais contar com duas câmaras. 
29. Reorganização do poder político institucional, estabelecendo um regime de governo semipresidencial.

30. Conformação de um forte aparato institucional de integração mista (privada e estatal) que se ocupe, como tema central, do futuro das gerações vindouras, assumindo o desafio das mudanças climáticas, da revolução digital, da automatização e das migrações, como tema de interesse essencial e permanente da sociedade e do Estado. Os governos, seja qual for sua vertente política, em estreita colaboração com esta institucionalidade, devem velar para que cada um dos habitantes do país possa enfrentar estes quatro desafios de maneira tal que não aprofundem a desigualdade material e de oportunidades, e que a dignidade de cada um esteja adequadamente respeitada.

31. O Estado do Chile deve fomentar a paz mundial, a tolerância e o respeito de todas as culturas, e contribuir para o desenho de uma ordem mundial respeitosa dos direitos humanos e da participação política. Deve se ocupar também de como incidir no desenho das políticas de exploração do universo e do futuro do território antártico com um estatuto que o assuma como reserva da vida humana ${ }^{37}$.

\section{Que semelhanças e diferenças podem ser assinaladas nos processos constitucionais recentes na Bolívia e no Equador e a experiência chilena atual? ${ }^{38}$}

Creio que se trata de experiências comparáveis apenas no que concerne à mobilização e repolitização que é característica dos três processos. A ausência no Chile de um movimento indígena de grandes proporções e o debilitado movimento sindical, assim como a ausência de uma liderança pessoal que conduza o processo, explicam suas diferenças. No Chile, os jovens do mundo da educação (escolar e universitária) e as mulheres são as forças sociais que impulsionam

\footnotetext{
${ }^{37}$ Para conhecer o alcance do debate relativo à nova normativa constitucional pode consultar, entre outros: Fuentes (2010); Sierra I. Lucas e Mac-Clure, Lucas (2011); Aguilar (2012); Jaraquemada, Jorge; Mery, Héctor (2013); Atria (2013); Palma, Eric Eduardo (2012b, 2013a, 2013b, 2013c); Zúñiga U., Francisco (2013, 2014); Revista de Derecho Público, Universidad de Chile (2014); Correa, Jorge (2014); CLAPES (2015); Palma, Eric Eduardo (2015a, 2015b, 2015c, 2016, 2017); Sierra, edit (2016); Chía y Quezada, eds.,(s.f.); Larraín, Felipe y Moreno, Francisco, eds., (2017).

${ }^{38}$ Ver: <https://scielo.conicyt.cl/scielo.php?script=sci_arttext\&pid=S0718-52002014000100010>.
} 
as mudanças. Suas demandas têm um componente mais próximo aos problemas da sociedade ocidental que a uma reivindicação da cultura indígena. Isto não quer dizer que esta demanda esteja ausente; de fato, a bandeira mapuche se hasteia ao lado da bandeira chilena. O que ocorre é que a reivindicação indígena não dará a nota de identidade do movimento, mas sim a profunda crítica ao modelo neoliberal extrativista e dependente do capitalismo estrangeiro, que golpeia também o meio ambiente. A disputa pela água tem também uma importância significativa e é em torno do direito à água que se produz o encontro entre o movimento indígena e o movimento ambientalista.

Por outro lado, tanto no Equador como na Bolívia houve assembleia constituinte. Os órgãos que redigiram o texto constitucional não suportaram as limitações que o poder constituído impôs ao órgão convencional chileno.

\section{Como é a participação de povos indígenas, negros, mulheres e organizações de trabalhadores no processo de demanda constituinte?}

Como assinalamos, os estudantes e as mulheres aportam o maior peso nas mobilizações. No Chile, a população afrodescendente tem escassa presença, porque é escasso o seu número, e está aproveitando a conjuntura para projetar sua organização. Nenhuma força política procurou interpretar suas demandas e eles mesmos não constituem uma força relevante, no entanto, a mesa de Unidade Social os considera um ator do processo. É altamente provável que no futuro se integrem com a população haitiana e aspirem a ter uma voz mais potente na política nacional. Nesta ocasião é difícil que isso ocorra.

O mundo dos trabalhadores tem uma significativa representação na chamada mesa de Unidade Social, ente que atuou em numerosas ocasiões em nome do movimento social. Trata-se de organizações de sindicatos de empresas privadas, de funcionários públicos e do mundo do professorado escolar.

\section{Na leitura política atual do contexto institucional chileno, quais são os maiores obstáculos para se estabelecer o processo constituinte?}


O maior obstáculo é o partido defensor da obra do ditador Augusto Pinochet, o chamado partido União Democrata Independente (UDI), que lidera a rejeição à nova Constituição. Também um pequeno partido de caráter fascista, de recente organização, o Partido Republicano. Em menor medida, também faz oposição ao processo um grupo de assembleias territoriais que conclamam à abstenção e à não participação no processo.

Mas o maior obstáculo é o voto voluntário. Não existe obrigação de votar no plebiscito que decidirá se se rejeita ou aprova a proposta de uma nova Constituição para o Chile.

Por certo, o Coronavírus está sendo aproveitado pela direita e pelo governo para tirar potência do movimento das ruas e mudar o foco da opinião pública. No entanto, alguns creem que a crise sanitária colocará em relevo, ainda com maior contundência, as iniquidades e injustiças do sistema.

\section{Considerações finais}

O processo constituinte que desenvolve atualmente no Chile tem antecedentes que remontam ao ano de 1978. A exigência de contar com uma nova Constituição, que privará de vigência a Carta Outorgada, inspirou a oposição até o início da década de 1980. Foi abandonada para dar passo à transição à democracia a partir do mês de outubro de 1988. Ao largo da década de 1990 e da primeira do século XXI, os partidos políticos opositores à ditadura aprofundaram as reformas à Constituição, com o propósito de originar uma nova Constituição, segundo um consenso que foi superado rapidamente, porque a reforma do ano de 2005 não foi aceita por todos como um novo texto constitucional. A partir do ano de 2006 é perfeitamente identificável um processo destinado a gerar um novo texto, mas como fórmula administrada pelos partidos políticos e pelo sistema institucional, descartando-se a via da assembleia constituinte. Paralelo a este processo, desde os primeiros anos do século XXI, distintas organizações da sociedade civil, assim como o movimento escolar e universitário, denunciaram a injustiça do modelo econômico

e levantaram a bandeira da assembleia constituinte como único mecanismo legítimo para se avançar para uma nova Constituição. O sistema institucional não deu resposta a estas demandas, gerando-se um divórcio entre partidos políticos e movimento social. 
Os protestos do mês de outubro do ano de 2019, desencadeados pela majoração das tarifas do Metrô, vincularam o descontentamento social de milhões de chilenas e chilenos com a exigência de uma nova Constituição via assembleia constituinte. A massividade, a eficácia dos protestos e a violência que os acompanhou, fizeram com que certos partidos políticos, e o governo que tinha cancelado todas as possibilidades para uma nova Constituição, procurassem conduzir o processo aprovando um itinerário constituinte no chamado "Acordo pela Paz Social e a Nova Constituição”. Dito acordo gerou as Leis n.21.200, n. 21.216 e n. 21.221, que contemplam distintas possibilidades: que o processo não se inicie porque a população rejeita ter uma nova Constituição; ou que se proceda à redação do texto por uma Convenção integrada por parlamentares e cidadãos eleitos (Convenção mista), ou por uma Convenção integralmente eleita e composta paritariamente por cidadãos e cidadãs (Convenção Constitucional). Este último órgão constituinte resultou seriamente limitado em suas faculdades pelo poder constituído, o que tem gerado todo um debate sobre se é ou não uma assembleia constituinte. O movimento social rechaça que tenha esse caráter e acusa os partidos políticos de desenharem um ente que servirá a seus interesses e não à maioria da população mobilizada contra o sistema econômico neoliberal e a Constituição de Pinochet. Um setor da sociedade civil agrupado em torno das chamadas assembleias territoriais tem convocado a não participação.

A maioria do movimento se inclina por avançar na organização local e territorial, derrotar os partidos políticos tradicionais e defender na Convenção uma normativa constitucional que supere o modelo neoliberal e atenda as demandas por um novo tipo de Estado, uma nova economia e uma ampliação do catálogo de direitos políticos, sociais, econômicos e culturais, assim como direitos coletivos vinculados às demandas dos povos indígenas. Cabe não perder de vista que os jovens e as mulheres tem sido os atores políticos com maior capacidade de instalação de suas demandas; de fato, as mulheres alcançaram a integração paritária. Espera-se que os constituintes convencionais eleitos pelo movimento possam questionar legitimamente os entraves da Convenção Constitucional e incidir nas características da nova ordem constitucional que se apresentará ao povo para ratificação ou rejeição. O povo do Chile deverá, em um plebiscito, pronunciar-se sobre o trabalho da Convenção (Misto ou Constitucional), aprovando ou rejeitando o novo texto constitucional. A rejeição à nova ordem constitucional poderia implicar a abertura para um novo processo constituinte. 


\section{Referências}

AGUILAR, Gonzalo. (Coord.). Derechos económicos, sociales y culturales en el orden constitucional chileno. Santiago de Chile: Librotecnia, 2012.

ATRIA, Fernando. La Constitución Tramposa. Santiago de Chile: LOM ediciones, 2013.

CLAPES - Centro Latinoamericano de Políticas Económicas y Sociales. Aportes para una Reforma Constitucional, serie Ideas para el debate, n. 3, Universidad Católica de Chile, Santiago de Chile, 2015.

CORREA, Jorge. ¿Ha llegado la hora de una nueva Constitución?. Anuario de Derecho Público UDP, 2013.

COUSO, Javier; CODDOU, Alberto. Las asignaturas pendientes de la reforma constitucional chilena. ICSO UDP, $\mathrm{n}^{\mathbf{o}}$ 2, 2009. (Working paper).

COUSO, Javier. A construção da "privatopia": o papel do direito constitucional na experiência neoliberal radical do Chile. Revista Culturas Jurídicas, V. 6, n. 15, p. 137-152, 2019. Disponível em: <http://www.culturasjuridicas.uff.br/index.php/rcj/article/view/909>.

CHIA, Eduardo; QUEZADA, Flavio (Eds.). (s.f.) Propuestas para una nueva Constitución (originada en Democracia), Santiago de Chile, 2015 (data possível de edição).

DIAZ DE VALDÉS, José M. La Reforma Constitucional del año 2005: contexto, impacto y tópicos pendientes. Revista Actualidad Jurídica, n² 20, julio, Tomo I. 2009.

FERNÁNDEZ SARASOLA, Ignacio. Sobre el objeto y el método de la Historia Constitucional Española”. Revista general de derecho constitucional, nº 5, 2008.

FERNÁNDEZ SARASOLA, Ignacio. La Historia constitucional: Método e Historiografía a la luz de un bicentenario Hispánico. Forum Historiae Iuris. 11 Jun. 2009. Disponível em <https://forhistiur.de/2009-06-sarasola/?L=es>.

FUENTES, Claudio (Coord.). En nombre del pueblo. Debate sobre el cambio constitucional en Chile. Santiago de Chile: Ediciones Böll Cono Sur, 2009. 
GRUPO DE ESTUDIOS CONSTITUCIONALES. La Constitución y la democracia en las proposiciones del grupo de los 24. Santiago de Chile, s.e., 1985.

ICHEH. Una salida político institucional para Chile, Instituto Chileno de Estudios Humanísticos. Santiago de Chile, 1985.

JARAQUEMADA, Jorge; MERY, Héctor. Ruptura o continuidad institucional: ¿necesita Chile una asamblea constituyente?. Anuario de Derecho Público, UDP, 2013.

LARRAÍN, Felipe; MORENO, Francisco (Eds.). Orden público económico y nueva Constitución. Centro UC. Clapes UC. 2017.

PALMA, Eric Eduardo. Tiempos de continuidad y cambio en el Derecho Chileno: 1973-2004. Persona y Sociedad, Volumen XVIII, nº 2, agosto, p. 95-110, 2004.

PALMA, Eric Eduardo. De la Carta Otorgada de 1980 a la Constitución Binominal de 2005. Revista Derecho y Humanidades, $n^{\circ}$ 13, p. 41-66, Santiago de Chile, 2008.

PALMA, Eric Eduardo. Pasado, presente y futuro de la Historia del Derecho en Chile. Revista electrónica alemana, Forum Historiae Iuris, 2009.

PALMA, Eric Eduardo Estado constitucional Liberal Católico en Chile (1812-1924). Nueva Historia Constitucional. $2^{\text {a }}$ Ed. Santiago: Facultad de Derecho, Universidad de Chile, 743 páginas. 2012a.

PALMA, Eric Eduardo. ¿Transando la Asamblea Constituyente?, 2 septiembre, 2012b. Disponível em: <https://www.elmostrador.cl/noticias/opinion/2012/09/02/transando-laasamblea-constituyente/>.

PALMA, Eric Eduardo. Un plebiscito, dos constituciones, 25 julio, 2013b. Disponível em <https://www.elmostrador.cl/noticias/opinion/2013/07/25/un-plebiscito-dos-constituciones/>.

PALMA, Eric Eduardo. La Constitución que queremos para el país que "queremos". 20 junio, 2013b. Disponível em: <https://www.elmostrador.cl/noticias/opinion/2013/06/20/laconstitucion-que-queremos-para-el-pais-que-queremos/>. 
PALMA, Eric Eduardo. Asamblea Constituyente vs. Vieja Concertación, 15 mayo, 2013c. Disponível em: <https://www.elmostrador.cl/noticias/opinion/2013/05/15/asambleaconstituyente-vs-vieja-concertacion/>.

PALMA, Eric Eduardo. 36 años demandando Asamblea Constituyente (1979-2015). In: GAETE, Manuel Fernández; CLAUDE, Cristián Figueroa (Eds.). Fumando Opio. De la Asamblea Constituyente al poder ciudadano. Santiago: Mutante Editores: Universidad Academia Humanismo Cristiano, Escuela de Historia, 2015a, p. 142-158.

PALMA, Eric Eduardo. Comentarios a la ponencia de Jorge Correa: del constitucionalismo tipo Estocolmo. Ciclo de Discusiones. Una Gran Conversación Por Chile. Proceso constituyente y nueva Constitución Política. Santiago: Facultad de Derecho, Universidad de Chile, 2015b, p. 62 66.

PALMA, Eric Eduardo. Del Constitucionalismo tipo Estocolmo y mezquino a la Constitución de la Dignidad Nacional. Democracia versus neoliberalismo. 25 años de neoliberalismo en Chile. Buenos Aires / Santiago: Editora Adriana Bazzi Pinol, ICAL, CLACSO, p. 329-348. 2015c.

PALMA, Eric Eduardo. $50+1$. Bicameralismo/Monocameralismo en perspectiva histórica y ciudadana. Revista Chilena de Derecho Parlamentario, nº 4, p. 46-52. 2016.

PALMA, Eric Eduardo. Derechos civiles y políticos: perspectiva histórica, derecho a la libre determinación y nueva Constitución vía Asamblea Constituyente. In: GAJARDO, Jaime. Nueva Constitución. Santiago de Chile: Editorial Rubicón, 2017.

PALMA, Eric Eduardo. Transformando en conservador un proceso emancipador. Radio Universidad de Chile, 21 de noviembre de 2019. Disponível em: <https://radio.uchile.cl/2019/11/21/transformando-en-conservador-un-proceso-emancipador/>. 2019a.

PALMA, Eric Eduardo. Del ruido de sables y el ruido de cacerolas, respuestas ante la cuestión social. El Desconcierto, 10 de noviembre de 2019. Disponível em: <https://www.eldesconcierto.cl/2019/11/10/del-ruido-de-sables-y-el-ruido-de-cacerolasrespuestas-ante-la-cuestion-social/>. 2019b. 
PALMA, Eric Eduardo. Que el sistema político responda al poder constituyente del "pueblo unido y despierto, El Desconcierto, 28 de octubre de 2019. Disponível em: <https://www.eldesconcierto.cl/2019/10/28/que-el-sistema-politico-responda-al-poderconstituyente-del-pueblo-unido-y-despierto/>. 2019c.

PALMA, Eric Eduardo; ELGUETA, María Francisca. Quiere usted una nueva Constitución. Editorial RIL (en prensa), Santiago de Chile. 2020.

SALINAS, Sergio. Conflicto y nuevos movimientos sociales. Santiago de Chile: Editorial RIL, 2016.

SIERRA, I. Lucas; MAC-CLURE, Lucas. Frente a la mayoría: leyes supramayoritarias y Tribunal Constitucional en Chile. Santiago de Chile: Centro de Estudios Públicos (CEP), Corporación de Estudios para Latinoamérica (CIEPLAN), Libertad y Desarrollo, Proyectamérica, 2011.

SIERRA, Lucas. Propuestas Constitucionales. Santiago de Chile: Centro de Estudios Públicos, 2016.

SOTO, Francisco. Asamblea constituyente: la experiencia latinoamericana y el actual debate en Chile. Revista Estudios Constitucionales, año 12, n. 1, 2016.

UNIVERSIDAD DE CHILE. Revista de Derecho Público. Número especial - Reformas Constitucionales, Facultad de Derecho, Universidad de Chile. 2014.

VARELA SUANZES-CARPEGNA, Joaquín. Algunas reflexiones metodológicas sobre la Historia Constitucional. Historia Constitucional - Revista Electrónica, nº 8, p. 246-259, 2007.

VARELA SUANZES-CARPEGNA, Joaquín. Algunas reflexiones metodológicas sobre la Historia Constitucional. Teoría y Realidad Constitucional, nº 21, p. 411-425, 2008.

VARELA SUANZES-CARPEGNA, Joaquín. Historia e historiografía constitucionales. Madrid: Editorial Trotta, 2015.

VIVEROS, Felipe. Sociedad civil y nueva Constitución: hacia un pacto ciudadano para la Constitución que queremos. Fundación Instituto de la Mujer / Movimiento Pro Emancipación de la Mujer Chilena (MEMCH). Santiago de Chile, 2006. 
ZÚÑIGA, Francisco. Vieja-nueva Constitución. Estudios Constitucionales, Centro de Estudios Constitucionales, Chile, v. 5, n. 1, 2007.

ZÚÑIGA, Francisco (Coord.). Reforma Constitucional. Santiago de Chile: Lexis Nexis, 2009. ZÚÑIGA, Francisco. Nueva Constitución y operación constituyente. Algunas notas acerca de la reforma constitucional y de la asamblea constituyente. Estudios Constitucionales, año 11, nº 1 , p. 511-540, 2013.

ZÚÑIGA, Francisco (Coord.). Nueva Constitución y Momento Constitucional. Visiones, antecedentes y debates. Santiago de Chile: Legal Publishing/Thomson Reuters, 2014.

ZÚÑIGA, Francisco. Nueva Constitución para Chile. Las bases y las nuevas ideas políticoconstitucionales. Revista de Derecho Público, Universidad de Chile, número especial, Reformas Constitucionales, Facultad de Derecho, Universidad de Chile, p. 25-40, 2014.

\section{Jornais consultados:}

Deutsche Welle: <https://www.dw.com/>.

El Ciudadano: <https://www.elciudadano.com/>.

El Desconcierto: <https://www.eldesconcierto.cl/> .

El Libero: <https://ellibero.cl/>.

El Mostrador: <https://www.elmostrador.cl/>.

Emol: <https://www.emol.com/>.

La Tercera: <https://www.latercera.com/>.

Radio Cooperativa: 〈https://www.cooperativa.cl/> .

Radio Universidad de Chile: <https://radio.uchile.cl/>.

\section{Páginas da web institucionais:}

Activa Research: <https://www.activasite.com/>. 
Centro de Estudios de Conflicto y Cohesión Social (COES): <https://coes.cl/>.

Centro de Estudios Públicos (CEP): 〈https://www.cepchile.cl/>.

Centro de Investigación Periodística (CIPER): 〈https://ciperchile.cl/sobre-ciper/>.

Instituto Nacional de Derechos Humanos: <https://www.indh.cl/>.

Fundación Patricio Aylwin: <http://fundacionaylwin.cl/>.

\section{Sondagens:}

CEP. Radiografía de la Opinión Pública Chilena Principales resultados del último Estudio Nacional de Opinión Pública del CEP. Centro de Estudios Públicos, Santiago de Chile, Junio, 2001.

CEP. Estudio Nacional de Opinión Pública, número 84, diciembre 2019. Centro de Estudios Públicos, Santiago de Chile, 2019.

DATAINFLUYE. Plebiscito, proceso constituyente y otras percepciones ciudadanas.

Estudio Cuantitativo. Enero, 2020. Disponível em: <https://www.tuinfluyes.com/assets/ estudios/ESTUDIO_TUINFLUYES_ENERO_PLEBISCITO_2020.pdf>.

NUDESOC. Informe sobre Encuesta Zona Cero realizada a manifestantes en Plaza

Dignidad durante el mes de noviembre. 2019. Disponível em: <https://www.uchile.cl/noticias/160656/estudiantes-caracterizaron-demandas-de-manifestantesde-la-zona-cero>. 